\title{
Effect of Vaman in Sthula Madhumeh and its impact on HOMA IR
}

\author{
Case Report
}

\section{Gopal Sagar Anil ${ }^{*}$, More Swapnalee Shankar'1, Gajbhiye Vaishali Krushnaji', Kabra PR ${ }^{2}$, Thatere $\mathbf{A A}^{3}$}

\author{
1. P.G Scholar, 2. Professor and HOD, 3. Assistant Professor, \\ Kayachikitsa Department, Government Ayurved College and Hospital, Nagpur.
}

\begin{abstract}
Background: Diabetes Mellitus is the most common metabolic disorder encountered in clinical practice. It is strongly linked to obesity. Diabetes mellitus is characterized by abnormal carbohydrate and lipid homoeostasis leading to elevation in plasma glucose or hyperglycemia. Diabetes can be related with Madhumeh (type of Prameha in which there is Madhurta of Tana i.e. body), which has been explained in Ayurvedic Samhitas. Prameha is especially characterized by Prabhut Matra and Avilata of Mutra with several abnormal qualities due Doshik imbalances. Charak concluded that if Prameha is not treated it ultimately progresses to Madhumeh. There is Madhurata of Mutra and Tanu in addition to polyuria. Charak classified Madhumeh of two types according to management viz Sthula and Krisha. Madhumeh is a disease in which excessive Santarpana is there. According to Vagbhata, Madhumeh is caused due to two causes such as Margavrodh and Dhatukshay. According to Charak depending on Brimhan Chikitsa is advised in patients having Krish Madhumeh with respect to its Bala. While Shodhan is indicated in the patients having Sthula Madhumeh, hence Vaman in the form of Shodhan Chikitsa is considered along with Nidanparivarjan to stablize the increased Kapha (Bahu Drava) and Kleda. Observations and results obtained during this case were encouraging and assessed on different parameters which are presented in full paper.
\end{abstract}

Key Words: Sthula madhumeh, Pachana, Triphaladi tailpana, Vaman, HOMA-IR.

\section{Introduction}

Type-2 diabetes occurs due to impaired insulin secretion, peripheral insulin resistance, and excessive hepatic glucose production. Insulin resistance impairs glucose utilization by insulin sensitive tissues and increase hepatic glucose output, both these effects contribute to the hyperglycemia. Increased hepatic glucose output predominantly accounts for increased fasting hyperglycemia, whereas decreased peripheral glucose uptake results rise in postprandial hyperglycemia (1). In Ayurved Acharya Charak has classified Prameha in two types i.e Sthula Pramehi and Krisha Pramehi Santarpanjanya and Apatarpanjanya Prameha it can also correlate with the classification given by Acharya Vagbhat, i.e Dhuatukshayajanya and Avarodhjanya Prameha respectively the factors which provokes the Vata directly cause Apatarpanjanya Prameha while the factor which provoke Kapha and Pitta cause Santarpanjanya Prameha. In Avaranajanya Prameha, Kapha is predominant Dosha, while the important Dushyas are Bahudravasleshma and Bahuabaddhameda are the basic pathological factors

\section{* Corresponding Author:}

\section{Gopal Sagar Anil}

PG scholar

Kayachikitsa Department,

Government Ayurved College and Hospital,

Nagpur. Maharashtra. India

Email Id: urvee92.solanki@gmail.com for Prameha. In Avaranjanya Samprapti, vitiated Kapha and Pitta obstruct the path of Vata, causing its provocation. Samshodhana is base treatment for the elimination of Doshas.

\section{Case Report}

A 49-year-old female patient having following complaints was came in OPD and admitted IPD of Kayachikitsa Department, Government Ayurved College, Nagpur.

\section{Chief Complaints}

Atikshudha, Sharirbharvriddhi, Sharir Gauravata, Ati-Sveda Pravritti, Ubhaya Padatala Daha, Daurbalya, Ubhay Janusandhishula and Asamyak Mala-Pravritti Since last 5 years and Aggravated in last 4 month.

\section{History of Present Illness}

Patient was healthy before 5 years. There was gradual increase in above symptoms, but above symptoms were aggravated in last 4 month. So for treatment, patient came to Kayachikitsa OPD and was admitted in Government Ayurveda College and Hospital, Nagpur for further treatment and management.

\section{Past History}

- Known case of Hypertension since last 2 years

- Known case of Diabetes mellitus 4 months. (on irregular medications) 
Present Medicinal History

- Tab. Telmikind-H (Telmisartan $40 \mathrm{mg}+$ Hydrochlorothiazide $12.5 \mathrm{mg}$ ) $1 \mathrm{OD}$

\section{Family History}

- Matruj Kula: Mrit H/O Throat Cancer.

- Pitruj Kula: Mrit H/O DM II.

- Past Surgical History: H/O: Tubectomy done 22 years ago in G.A.C.H. Nagpur

- Ashtavidha Parikshan: WNL except Asamyak Mala Pravritti, Atimutra Pravritti, Jivha Samata, Sthula Akriti (Wt- $65 \mathrm{~kg}$, Height:150 cm and BMI:28.9)

\section{Vikrut Strotas Parikshan}

- Strotas Parikshan WNL Exept,

- Udakvaha Strotasa: Ati-Pipasa,

- Annavaha Strotasa: Jivha Samata,

- Rasavaha Strotasa: Tandra, Gauravata, Angamarda.,

- Mansavaha Strotasa: Sakashta Chankramana,

- Medovaha Strotasa: Stanodar Lambanam, Sharirbhar Vriddhi, Ubhaypadatal-Daha,

- Asthivaha Strotasa: Ubhaya Janusandhi Shula.

- Purishvaha Strotasa: Asamyak Mala-Pravritti,

- Mutravaha Strotasa: Ati-Mutra Pravritti,

- Svedavaha Strotasa: Ati- Sveda Pravritti.

Investigations: $24 / 02 / 2020$

- CBC: WNL, Urine Routine and Microscopic Examination: WNL.

- BSL: Fasting-124 mg/dl, PP-231 mg/dl, ECG: WNL.

- Lipid Profile: Total Cholesterol 188, HDL: 40, Triglyceride -101, LDL:101

- Sr. Insulin(F): 16.89, HOMA-IR (2): 5.21

\section{Management}

- Initially Pachan Chikitsa was given $40 \mathrm{ml}$ Pachhatbhakta is given as a Pachana for 5 days.(3)

- Then, Snehapana (4) with Triphaladi-Tail (5) in Vardhamana Matra at morning empty stomach for 7 Days till patient showing_Snehapana SiddhiLakshana, (6) Snehan-Svedan (Rest Day) (7) was given on $8^{\text {th }}$ day and on the day of Vaman, then Vaman Karma At morning on day of Vaman,
Sarvanga Abhaynga with Til Taila and Peti Svedan was given. Then Vacha Siddha Dugdha 200ml was given, Chatan Dravya as Yastimadhu $10 \mathrm{gm}$, Madanpiappali 5 gm, Vachachurna 2.5 gm, Saidhav 5 gm, Pippalichurna $2.5 \mathrm{gm}$ and Madhu as per need then Madanphala Pippali Yastimadhu Phanta given for Vamana. After Vaman, Paschat Karma (8) Dhumapana is given With Haridra and Ajvayan

- Shuddhi: Pravar, Antiki: Pittanta, Laingiki: Daurbalya, Udarlaghavata,

- Sansarjana Kram (9) is given for 7 days as explained in Ayurvedic Literature.

\section{Observation and Results}

Table-1: Table showing Effect of Therapy on Blood Sugar Level and Sr. Insulin

\begin{tabular}{|c|c|c|}
\hline Date & $\begin{array}{l}25 / 02 / 20 \\
\text { (Before } \\
\text { Treatment) }\end{array}$ & $\begin{array}{c}14 / 03 / 20 \\
\text { (After } \\
\text { Samsrjan-Krama) }\end{array}$ \\
\hline Fasting & $124 \mathrm{mg} / \mathrm{dl}$ & $98 \mathrm{mg} / \mathrm{dl}$ \\
\hline Post-Prandial & $231 \mathrm{mg} / \mathrm{dl}$ & $130 \mathrm{mg} / \mathrm{dl}$ \\
\hline Serum Insulin & $16.89 \mathrm{mlU} / \mathrm{L}$ & $12.9 \mathrm{mlU} / \mathrm{L}$ \\
\hline HOMA-IR & 5.21 & 3.12 \\
\hline
\end{tabular}

Table-2 Table showing Effect of Therapy on BMI

\begin{tabular}{|c|c|c|c|c|c|c|} 
Date & Ht & Wt & $\begin{array}{c}\text { BMI } \\
\mathbf{9 ( K g} \\
\left(\mathbf{m}^{2}\right)\end{array}$ & Waist & Hip & $\begin{array}{c}\text { W:H } \\
\text { Rati } \\
\mathbf{0}\end{array}$ \\
\hline $\begin{array}{c}25 / 02 \\
120\end{array}$ & $\begin{array}{c}150 \\
\mathrm{~cm}\end{array}$ & $65 \mathrm{~kg}$ & 28.9 & $84 \mathrm{~cm}$ & 105 & 0.8 \\
\hline $\begin{array}{c}14 / 03 \\
120\end{array}$ & $\begin{array}{c}150 \\
\mathrm{~cm}\end{array}$ & $59 \mathrm{~kg}$ & 26.2 & $82 \mathrm{~cm}$ & $\begin{array}{c}103 \\
\mathrm{~cm}\end{array}$ & 0.79 \\
\hline
\end{tabular}

Table- 3 Table showing Effect of Therapy on Lipid Profiles

\begin{tabular}{|c|c|c|}
\hline Date & $\begin{array}{c}\mathbf{2 5 / 0 2 / 2 0 2 0} \\
(\mathbf{B T})\end{array}$ & $\begin{array}{c}\mathbf{1 4 / 0 3 / 2 0 2 0} \\
(\mathbf{A T})\end{array}$ \\
\hline Total Cholesterol & $188 \mathrm{mg} / \mathrm{dl}$ & $178 \mathrm{mg} / \mathrm{dl}$ \\
\hline L.D.L & $127.8 \mathrm{mg} / \mathrm{dl}$ & $117.6 \mathrm{mg} / \mathrm{dl}$ \\
\hline H.D.L & $40 \mathrm{mg} / \mathrm{dl}$ & $38 \mathrm{mg} / \mathrm{dl}$ \\
\hline Triglyceride & $101 \mathrm{mg} / \mathrm{dl}$ & $112 \mathrm{mg} / \mathrm{dl}$ \\
\hline
\end{tabular}

Table-4 Table showing Effect of Therapy on Signs and Symptoms (10)

\begin{tabular}{|c|c|c|c|c|c|c|}
\hline Symptoms & Gradation & & & Grade & BT & AT \\
\hline Unexplained & \multicolumn{3}{|c|}{ Weight gain $>6 \mathrm{kgs}$.than max range for BMI 23} & 3 & \multirow{4}{*}{3} & \multirow{4}{*}{2} \\
\hline \multirow[t]{3}{*}{ Weight gain } & \multicolumn{3}{|c|}{ Weight gain 3-5kgs.than max range for BMI 23} & 2 & & \\
\hline & \multicolumn{3}{|c|}{ Weight gain 1-2kgs.than max range for BMI 23} & 1 & & \\
\hline & \multicolumn{3}{|c|}{ No Weight gain } & 0 & & \\
\hline \multirow[t]{5}{*}{ Shithilangata } & & Male & Female & Grade & \multirow{5}{*}{3} & \multirow{5}{*}{2} \\
\hline & Abdominal girth & $>102 \mathrm{~cm}$ & $>88 \mathrm{~cm}$ & 3 & & \\
\hline & Abdominal girth & $>98-102 \mathrm{~cm}$ & $84-88 \mathrm{~cm}$ & 2 & & \\
\hline & Abdominal girth & $94-98 \mathrm{~cm}$ & $80-84 \mathrm{~cm}$ & 1 & & \\
\hline & Abdominal girth & $<94 \mathrm{~cm}$ & $<80 \mathrm{~cm}$ & 0 & & \\
\hline \multirow[t]{4}{*}{ Kshudhativriddhi } & \multicolumn{3}{|c|}{$\begin{array}{l}\text { Requires total } 2 \text { meals and heavy breakfast/extra meal still feels } \\
\text { hungry. }\end{array}$} & 3 & \multirow{4}{*}{3} & \multirow{4}{*}{2} \\
\hline & \multirow{3}{*}{\multicolumn{3}{|c|}{$\begin{array}{l}\text { Requires total } 2 \text { meals and heavy breakfast/extra meal to satisfy } \\
\text { Requires total } 2 \text { meals and light breakfast/extra light meal to satisfy } \\
\text { Two meals a day with light breakfast satisfies hunger. }\end{array}$}} & 2 & & \\
\hline & & & & 1 & & \\
\hline & & & & 0 & & \\
\hline
\end{tabular}


Fatigue

Sheetpriyata,

Svapna, Sukhe arati

Kar Pada Suptata

\section{Dantadinam \\ Maladhyatvam}

Kar Pada Daha
Feeling of Tiredness for whole day

Feeling of Tiredness for half day

Feeling of Tiredness for 6-8hrs a day

Never in a day

Feels good while sleeping than lying.

Feels good while lying than sitting.

Feels good while sleeping than lying.

Feels good while walking/ standing than sitting

Severe Continuous tingling sensation disturbs routine activity.

Continuous tingling sensation that does not disturb routine activity

Intermittent tingling sensation that does not disturb routine activity

No tingling sensation

Very frequently infection occurs.

Recurrency of infection is intermittent.

Recurrency of infections is occasional

No infection

Severe burning sensation disturbs routine activity.

Continuous burning sensation that does not disturb routine activity

Intermittent burning sensation does not disturb routine activity

No Burning Sensation

Require additional water $>3$ litre more than normal still feels thirsty.

Require two fold additional water than normal.(2.5-3lit)

Require more additional water than normal (2-2.5lit)

Daily normal quantity of water to quench thirst $(<=2$ lit)

Swedatipravritti at rest

Swedatipravritti on little exertion

Swedatipravritti on more exertion

No Swedapravritti.

Require A.C./fan 24 hours.

Requires A.C/fan 12hours

Requires A.C/fan 6-8hours

Requires no A.C./ high speed fans.

Feeling of sweet taste all while

Feeling of sweet taste after eating Madhur, Amla, Lavana substances.

Feeling of sweet taste for considerable period only after eating sweet

No feeling of sweetness in mouth.

\begin{tabular}{|c|c|c|}
\hline & \multirow{3}{*}{3} & \multirow{3}{*}{2} \\
\hline 1 & & \\
\hline 0 & & \\
\hline 3 & \multirow{3}{*}{2} & \multirow{3}{*}{1} \\
\hline 2 & & \\
\hline 0 & & \\
\hline 3 & \multirow{3}{*}{1} & \multirow{3}{*}{1} \\
\hline 2 & & \\
\hline$\frac{1}{0}$ & & \\
\hline 3 & \multirow{3}{*}{3} & \multirow{3}{*}{2} \\
\hline 2 & & \\
\hline $\begin{array}{l}1 \\
0\end{array}$ & & \\
\hline 3 & \multirow{4}{*}{2} & \multirow{4}{*}{1} \\
\hline 2 & & \\
\hline 1 & & \\
\hline 0 & & \\
\hline 3 & \multirow{3}{*}{3} & \multirow{3}{*}{2} \\
\hline $\begin{array}{l}2 \\
1\end{array}$ & & \\
\hline 0 & & \\
\hline 3 & \multirow{3}{*}{3} & \multirow{3}{*}{2} \\
\hline 2 & & \\
\hline 0 & & \\
\hline 3 & \multirow{3}{*}{3} & \multirow{4}{*}{2} \\
\hline 2 & & \\
\hline 1 & & \\
\hline 3 & \multirow{3}{*}{2} & \\
\hline 2 & & \multirow[t]{2}{*}{1} \\
\hline & & \\
\hline
\end{tabular}

\section{Discussion}

Prevalence of diabetes mellitus is rapidly growing throughout the globe at alarming rate, where India leads and might be a diabetic capital of world in future. Currently available conventional options for diabetes have certain limitations. Considering those limitations, alternative resources are being search to meet the need. Ayurved, the traditional system of Indian medicine has its own views. By virtue of fact of "Madhuryat Cha Tanorata" the disease is termed as Madhumeh. Though involvement of Tridosha is there, dominance of Vata is there. Bahudravashleshma, Abaddha Meda are predominantly involved along with Rakta, Shukra, Ambu, Vasa, Lasika, Majja, Rasa, Oja and Mansa (11) The main pathogenesis occurs due to the Kleda Vriddhi. There may be Strotas Avarodh (Avritatva), or Dhatu Kshaya (12) so that pathogenesis is further enhanced by virtue of Prakopa of Vata.

In this case of Madhumeh patient was selected considering BMI more than $23 \mathrm{~kg} / \mathrm{m}^{2}$, it was $28.9 \mathrm{~kg} / \mathrm{m}^{2}$ before treatment along with symptoms of Kapha, Meda, Rasa and Rakta Dushti. Accordingly, treatment was planned and Vaman was administered with prior Pachana proceeded by Snehapana. After administration of Vaman and Samsarjan Krama, BMI came down from
$28.9 \mathrm{~kg} / \mathrm{m}^{2}$ to $26.2 \mathrm{~kg} / \mathrm{m}^{2}$ as well as symptoms of Kapha, Meda, Rasa and Rakta Dushti were reduced remarkably. Positive results described on blood sugar level, HOMA-IR, BMI, lipid levels and symptoms score respectively in Table-1,2,3 and 4 are self-explanatory that Vaman has beneficial effect on disease, manifested because of involvement of Kapha Dosha and Meda Dushti. Two causes are contemplated to manifest Madhumeh, a type of Vataj Prameha. Charak has expounded that Madhumeh because of Dhatu Kshaya has no treatment (13). Sthul Madhumeh is because mainly due to Bahudravasleshma can be some sort of target tissue defect and Bahu-abaddhameda can be correlated with free fatty acids, which are released from intra-abdominal central adipose tissues. Free fatty acids may cause insulin resistance (14). As far as Vaman is concerned it lessens primarily Kapha and to some extent Pitta also (15). Here Vaman seems to decrease the peripheral insulin resistance in muscles by alleviating Bahudravasleshma and so helping to increase the glucose uptake. As Vaman also reduces the $M e d a$, it must be promoting the function of insulin by reducing the circulating free fatty acids in the body (16). By this it can be justified its role in reducing both FBS and PPBS considerably. Though, results in this 
case is based on only one case, the treatment can be planned based on Dosha Pratyanika Chikitsa. So that one can conclude that Vaman is the best treatment for vitiated Kapha and Dushta Meda.

\section{Conclusion}

In this case study, there is reduction in objective parameters specially in the insulin resistance in type 2 diabetes mellitus. The Ayurvedic Concepts in Diabetes, having fruitful effect; be planned and evaluated systematically, adopting meticulous methods.

\section{References}

1. Kasper D.L, Fauci A.S, Longo, Braunwald J, Hauser S.L, editors. Harrison's Principles of Internal Medicine. 16th ed. Ch 323. Vol. 2. New York, NY: McGraw-Hill; 2005. 2157p.

2. John John k., Shetty S., Rao A.V., Metabolic syndrome, central obesity and Insulin Resistance among Medical Students: 2016.

3. Gupta K, Ashtanga Hrudaya Sutrasthan 16/37, 38, Chaukhambha Prakashan-Varanasi; 2019. 149p.

4. Gupta K, Ashtanga Hrudaya Sutrasthan 16/17-18, 38, Chaukhambha Prakashan-Varanasi; 2019. 147p.

5. Tripathi I, Chakradatta Chikitsasthan 36/31, 32, 33, Chaukhambha Sanskrit Bhavan-Varanasi; 2018. $223 p$.

6. Gupta K, Ashtanga Hrudaya Sutrasthan 16/30, Chaukhambha Prakashan-Varanasi; 2016. 149p.

7. Tripathi B, Charak Samhita-Kalpasthan-1/14, Chaukhambha Surbharati Prakashan-Varanasi; 2016. 1080p.
8. Tripathi B, Charak Samhita-Sutrasthana-15/14, Chaukhanbha Surbharati Prakashan-Varanasi; 2017. $316 \mathrm{p}$.

9. Gupta K, Ashtanga Hrudaya Sutrasthan 18/28-29, Chaukhambha Prakashan-Varanasi; 2016. 157p.

10. Aswar S.A, Camparative study on Asanadi Yoga with Shalvarga and Metformin on Sthoola Madhumeh with special reference to type 2 Diabetes mellitus specially on HbAlc and Lipid profile; 2019.

11. Tripathi B, Charak Samhita; Chikitsasthan-6/8: Chaukhambha Surbharati Prakashan-Varanasi; 2016. 281p.

12. Gupta A, Astang-Hridaya-Nidan-10/18, Chaukhambha Prakashan Varanasi; 2019. 347p.

13. Tripathi B, Charak Samhita-Chikitsasthan-6/52, Chaukhambha Surbharati Prakashan-Varanasi; 2016. 294p.

14. Frier BM, Fisher M. Diabetes mellitus. In: Boon NA, Colledge NR, Walker BR, Hunter JA, editors. Davidson's Principals and Practice of Medicine. 20th ed. London: Churchill Livingstone, Elsevier; 2006. 813p.

15. Gupta K, Ashtanga Hrudaya Sutrasthan 18/1, 38: Chaukhambha Prakashan-Varanasi; 2019. 154p

16. Kaviraj Ambikadutt Shastri: Sushruta. 14th ed. Varanasi: Chukhabha Sanskrit Sansthan; Reprint; 2003. Sushruta Samhita with Ayurveda-TattvaSandipika Commentry; Chikitsa Sthana 33/18, $143 p$. 